\title{
POROČILO O STANJU OKOLJA V MESTNI OBČINI KOPER
}

\author{
Santina Lavrič*, Sara Strajnar' \\ Študentki geografije na Oddelku za geografijo Filozofske fakultete Univerze v Ljubljani, \\ Aškerčeva 2, SI - 1000 Ljubljana, Slovenija \\ e-mail: santina.lavric@gmail.com
}

Strokovni članek

COBISS 1.04

\section{Izvleček}

Članek je povzetek Poročila o stanju okolja za Mestno občino Koper in obravnava stanje posameznih pokrajinotvornih sestavin, kot so površinske vode, morje, zrak in prst; predstavi pa tudi problematiko ravnanja $\mathrm{z}$ odpadki in z zavarovanimi območji narave.

Ključne besede: Mestna občina Koper, stanje pokrajinotvornih sestavin, DPSIR model

\section{REPORT ON THE STATE OF THE ENVIRONMENT IN THE MUNICIPALITY OF KOPER}

\begin{abstract}
The article is an extract of the Report on the state of the environment in the Municipality of Koper and discusses the state of individual environmental components, such as surface water, sea, air and soil. It also presents problems with waste management and with management of terrestrial and marine protected areas.
\end{abstract}

Key words: Municipality of Koper, state of the environmental components, DPSIR model

\footnotetext{
${ }^{1}$ Pri raziskovalni nalogi so sodelovali še: Zala Ašič, Martin Bajželj, Rok Ciglič, Lucija Dornik, Doris Gumilar, Katarina Klöckl, Aleš Krže, Klemen Lebar, Mladen Novak, Polona Pekolj, Tanja Plešivčnik, Metka Pogačnik, Ksenija Poredoš, Žiga Prelec, Matjaž Rotenhajzer, Amir Suljić, Jaka Šimnovec, Janja Šrubar, Darko Štamcar, Ula Zupan in Anita Žalik.
} 


\section{UVOD}

Pri študiju geografije so vedno bolj pomembni in prisotni samostojni študentski raziskovalni projekti, praktični pristopi in sodelovanje z različnimi institucijami, tako na lokalni kot na državni ravni. Rezultat takega sodelovanja med Oddelkom za geografijo in Mestno občino Koper je Poročilo o stanju okolja v Mestni občini Koper (v nadaljevanju MO), ki smo ga v letu 2006 pripravili študentje pri usmeritvi Varstvo geografskega okolja.

Koncept naše raziskave je izhajal iz integralnega geografskega modela raziskovanja okolja in sestavin okolja, katerega osnova je DPSIR model (Driving forces - gonilne sile, Pressures - pritiski, States - stanja, Impacts - vplivi, Responses - odzivi (Das DPSIR, 2006)), kjer obremenitve oziroma pritiske na sestavine okolja povzročajo gospodarske dejavnosti, sestavine pa se v odvisnosti od samočistilnih in regeneracijskih sposobnosti odzivajo na pritiske in rezultat teh procesov je stanje okolja. Obravnavali smo posamezne pokrajinotvorne sestavine (vode, zrak, prst) in izpostavili problematiko ravnanja z odpadki in z zavarovanimi območji narave.

Shema 1: DPSIR model

Scheme 1: DPSIR model

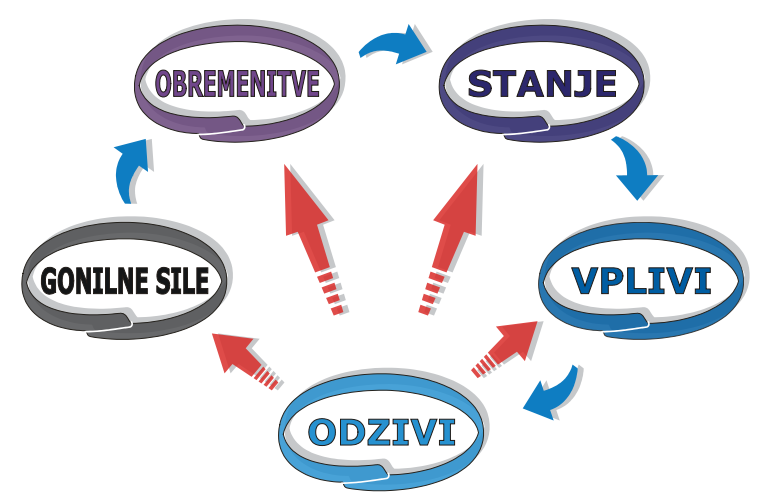

\section{VODE}

V MO Koper je pitna voda dragocena dobrina. Zagotavljanje nemotene oskrbe s pitno vodo je problematično in omejeno z izdatnostjo vodnih virov, hkrati pa so ob najmanjši razpoložljivosti virov potrebe po vodi največje. V sistemu Rižanski vodovod Koper za zajetje pitne vode koristijo tri vodne vire, poleti pa črpajo vodo še iz vodnih virov v Grandolah na Hrvaškem (preko Istrskega vodovoda Buzet, 20,8 \%) in iz Kraškega vodovoda Sežana (okoli 7,8 \%). Zaradi visokih stroškov oskrbe je cena vode najvišja v Sloveniji; gospodinjstva morajo plačati 554,8 SIT (2,32€) za m³ vode (skupaj s kanalščino), medtem ko cena v Ljubljani znaša le $214,8 \mathrm{SIT} / \mathrm{m}^{3}$ (0,90 €) (Medmrežje 1: Javno podjetje vodovod - kanalizacija Ljubljana, 2006; Medmrežje 4: Rižanski vodovod Koper, 2006). 
Kvaliteta pitne vode ustreza zdravstvenim kriterijem. Rižanski vodovod uspešno zmanjšuje izgubo vode, saj je leta 1987 izgubljena voda predstavljala 43 \% vse oddane vode, leta 2006 so znašale izgube le 29 \%. Izgube vode so posledica dejanskih (npr. puščanje cevi zaradi posedanja tal) ali navideznih (napake pri merjenju) izgub vode. Koprsko vodovodno omrežje je zelo razvejano, skupna dolžina znaša že več kot 900 kilometrov (Medmrežje 4: Rižanski vodovod Koper, 2006). Med letoma 1994 in 2005 je količina prodane vode bolj ali manj konstantna in se giblje okrog 3 milijonov $\mathrm{m}^{3}$ vode. Iz spodnjega grafa je razvidno, da je bila v tem obdobju največja poraba leta $2003\left(3.289 .443 \mathrm{~m}^{3}\right)$, vzrok zato je dalj časa trajajoče sušno obdobje.

Grafikon 1: Prodana voda v MO Koper v obdobju 1994-2005

Graph 1: Sold water in the Municipality of Koper between 1994 and 2005

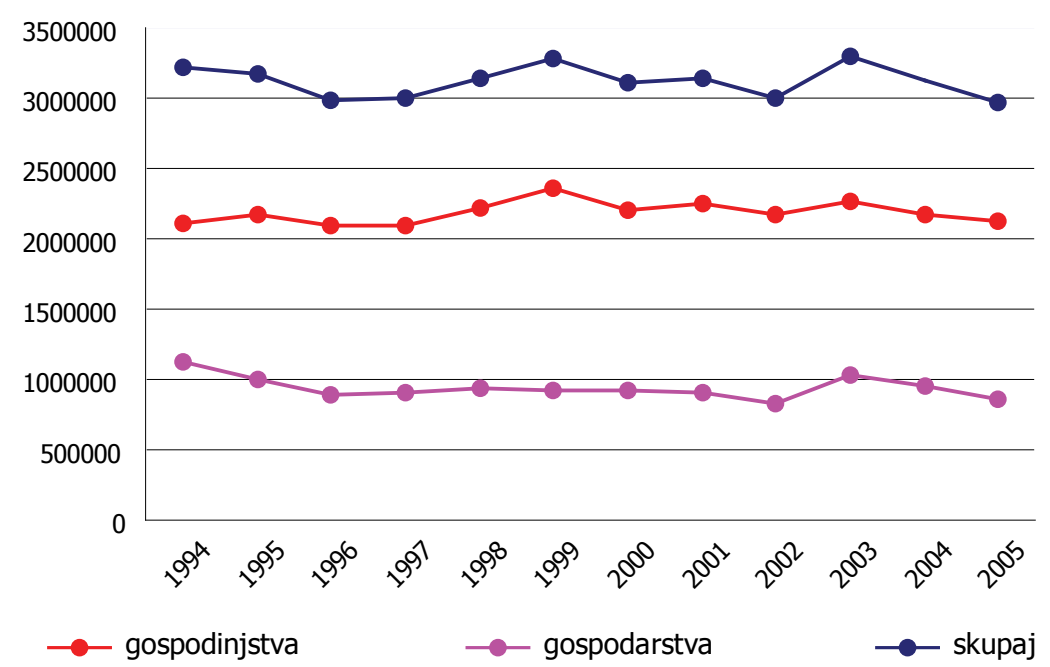

Vir: Rižanski vodovod Koper, 2006.

Kljub temu da industrija uporablja vedno čistejše tehnologije, so pri obremenjevanju velikih podjetij problematične odpadne vode. Glavni onesnaževalci reke Rižane so Lama Dekani, Kemiplas, Celanese Polisinteza in Luka Koper. Onesnaževalec povodja Drnice je KIO Šmarje, ki proizvaja tehnološke in sanitarne odpadne vode. Onesnaževalci reke Badaševice so Cimos, Tomos in Vinakoper. Večina industrijskih naprav ima urejen iztok odpadnih voda v kanalizacijo, ki se zaključi s čistilno napravo. Največ odpadnih voda proizvede Kemiplas, sledijo mu Tomos, Vinakoper in Lama.

Reka Rižana spada v 2. - 3. kakovostni razred, za reko Dragonjo v MO Koper ni merilnega mesta, saj meritve opravljajo izven občine v Podkaštelu. Leta 2003 in 2004 je bilo ocenjeno kemijsko stanje za Rižano in za Dragonjo dobro. Skoraj 50.000 prebivalcev v MO Koper je priključeno na devet čistilnih naprav. 
Karta 1: Čistilne naprave v MO Koper

Map 1: Water treatment plants in the Municipality of Koper

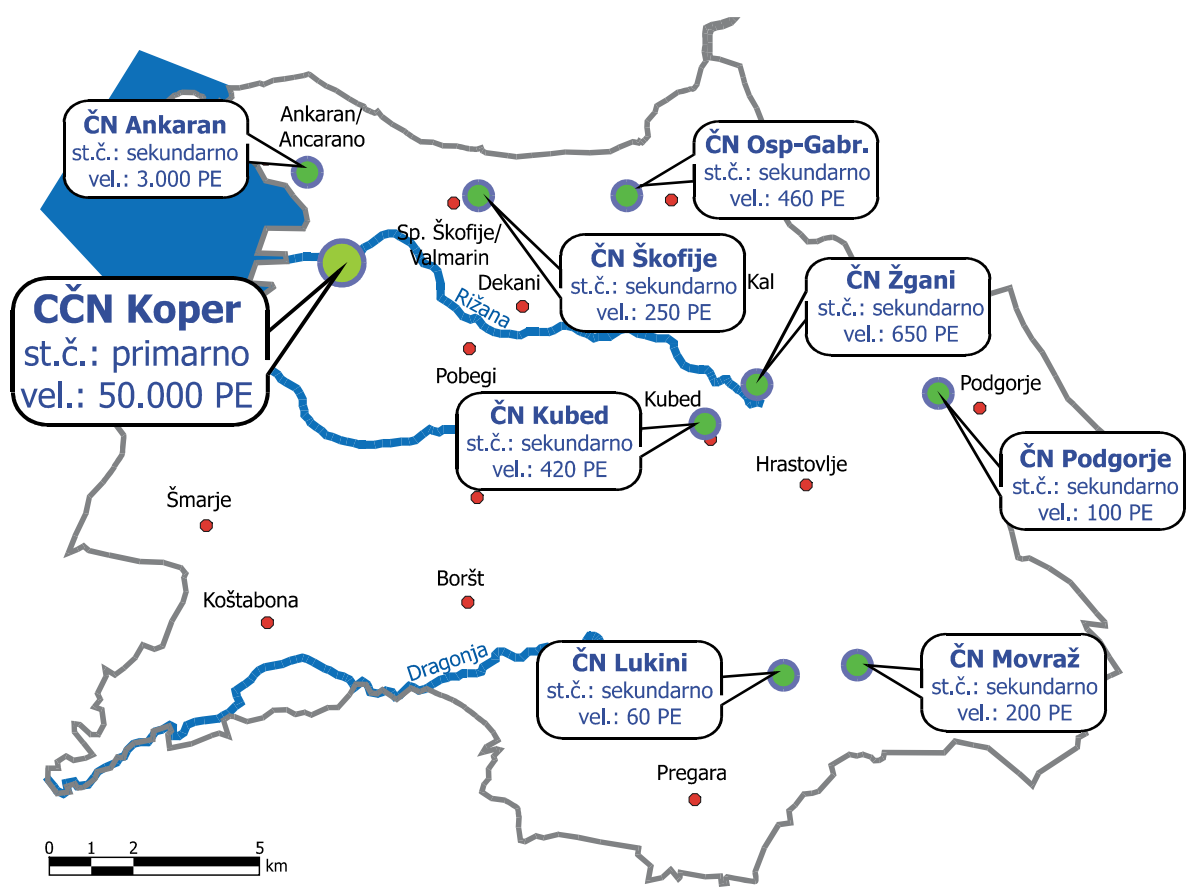

Vir: Medmrežje 2: Komunala Koper, 2006. Avtor: Novak, 2006.

\section{MORJE}

Za Tržaški zaliv so značilni počasno kroženje vode, plitkost in velik vpliv celinskih voda na kakovost morske vode, zato je slovenski del zaliva še posebej občutljiv na onesnaženja. V skladu s pomenom ohranjanja biotske raznovrstnosti je Slovenija petino morske obale s pripadajočim akvatorijem razglasila za zavarovano območje. V teh območjih potekajo okolju prilagojene gospodarske dejavnosti, med katerimi je najpomembnejše solinarstvo.

Skoraj 60\% stalno naseljenega prebivalstva v MO Koper je priključenega na javni kanalizacijski sistem, ki se konča z osrednjo čistilno napravo ob ustju Rižane. V občini je še 4.500 greznic, ostale odpadne vode pa se neprečiščene izlivajo v Koprski zaliv preko Badaševice in preko izpusta na ankaranski strani zaliva. V morje se spirajo tudi meteorne vode urbaniziranih površin (Zmanjševanje onesnaževanja Koprskega zaliva, 2004).

Komunalna čistilna naprava Koper ima zaenkrat urejeno le mehansko čiščenje, ki samo zmanjša količino trdnih odpadkov, tako da se na koncu v Koprski zaliv izliva dokaj onesnažena voda. Večji onesnaževalci morja so podjetja, ki bodisi nimajo čistilne naprave in odpadne vode spuščajo neposredno v kanalizacijo (Celanese Polisinteza, delno Kemiplas, 
Lama) bodisi imajo odtok neposredno v okolje (Dinos, Instalacije, delno Kemiplas, Luka Koper, Primorje in Tropex). Potencialno grožnjo za onesnaženje morja zaradi svoje razvejane dejavnosti predstavlja Luka Koper, predvsem gre za onesnaženje z nafto in drugimi nevarnimi snovmi.

Preglednica 1: Tip iztoka odpadne vode

Table 1: Waste water discharge type

\begin{tabular}{|l|c|c|c|}
\hline & $\begin{array}{c}\text { Iztok v kanalizacijo, } \\
\text { ki se ne zaključi s KČN }\end{array}$ & $\begin{array}{c}\text { Iztok v kanalizacijo, } \\
\text { ki se zaključi K KČN }\end{array}$ & $\begin{array}{c}\text { Iztok neposredno } \\
\text { v okolje }\end{array}$ \\
\hline Alcan Tomos & & $\mathrm{X}$ & \\
\hline Avtosan Plus & & $\mathrm{X}$ & \\
\hline Avtopralnica Trošt & $\mathrm{X}$ & $\mathrm{X}$ & \\
\hline Celanese Polisinteza & & $\mathrm{X}$ & $\mathrm{X}$ \\
\hline Cimos & & $\mathrm{X}$ & $\mathrm{X}$ \\
\hline Citroën & & $\mathrm{X}$ & $\mathrm{X}$ \\
\hline Dinos & & $\mathrm{X}$ & $\mathrm{X}(\mathrm{del})$ \\
\hline Gold Koper & & $\mathrm{X}$ & \\
\hline Instalacije & & $\mathrm{X}(\mathrm{del})$ & \\
\hline Interevropa & & $\mathrm{X}$ & \\
\hline Kemiplas & & & \\
\hline Lama & & & \\
\hline Luka Koper & & & \\
\hline Mlinotest Kruh & & & \\
\hline Primorje & & & \\
\hline Surovina & & & \\
\hline Tomos & & & \\
\hline Tropex & & & \\
\hline Vinakoper & & & \\
\hline
\end{tabular}

Nacionalni inštitut za biologijo za MOPE-ARSO izvaja meritve kakovosti morja, brakičnih voda in voda za življenje in rast školjk in morskih polžev. Problem v Tržaškem zalivu je nasičenost s kisikom, posebej padec pod $2 \mathrm{mg} / \mathrm{l}$, katerega posledica je anoksija zaradi katere poginejo organizmi v pridnenem sloju. Take razmere so bile zadnjič leta 1993 in 1994 (Poročilo o stanju..., 1996). Izredni pojavi evtrofizacije prav tako predstavljajo resen problem, saj se zaradi prekomerne rasti fitoplanktona zmanjša vsebnost kisika. Glede težkih kovin je v stalnih preseganjih baker ter ponekod celokupni krom in nikelj. Vsebnosti kadmija, živega srebra in alifatskih ogljikovodikov so višje na postaji pred Marino Koper v primerjavi z rezultati v Strunjanu. Sanitarna kakovost kopalnih voda je najslabša na kopališču Ankaran-Adria, na naravnem kopališču Debeli Rtič so bile presežene vrednosti koliformnih 
bakterij, medtem ko so bili na kopališču Žusterna in Mestnem kopališču Koper vsi izmerjeni parametri pod priporočeno mejo (Poročilo Evropski komisiji o izvajanju direktive o kopalnih ..., 2006).

\section{ZRAK}

Na kakovost zraka v občini Koper vplivajo promet, industrija, Luka Koper in posamezna kurišča. Industrija in promet onesnažujeta zrak celo leto, medtem ko so kurišča vir emisij v hladni polovici leta. V okviru meritev so bile mejne emisijske koncentracije za ozon in prašne delce nekajkrat presežene. Meritve ostalih onesnažil niso presegale z zakonom dovoljenih vrednosti. Kažejo pa se negativni učinki čezmejnega onesnaževanja, katerega vir je industrijsko območje v Padski nižini v Italiji.

Koncentracija delovnih mest v priobalnem pasu povzroča velike vsakodnevne migracije delovne sile. V MO Koper je razvit cestni, železniški in ladijski promet, občina pa je pomembna zaradi tranzitne lege med notranjostjo in obalnim delom Slovenije. Prometne emisije so dušikovi oksidi, ogljikov monoksid, prašni delci in lahko hlapne organske snovi (benzen, toluen, etil-benzen, ksilen, vinilacetat, ortoksilen in formaldehid).

Industrija je vir emisij dušikovih oksidov, ki nastajajo pri kurjenju fosilnih goriv in pri sežiganju tekočih odpadkov. Prav tako je pomemben vir prašnih delcev, hrupa in emisij lahko hlapnih organskih snovi (benzen, toluen, ksilen, vinilacetat, ortoksilen, formaldehid), ki se pojavijo pri skladiščenju naftnih derivatov in drugih lahko hlapnih snovi.

Glavnina industrije v MO Koper je skoncentrirana na območju mesta Koper, v Dekanih in v Luki Koper. Znatnejše vplive na onesnaževanje zraka imajo večja podjetja, kot so Luka Koper, Kemiplas, Cimos, Alcan Tomos, Lama, Tomos, Celanese Polisinteza in drugi. Od teh pa nobeno prekomerno ne izstopa glede onesnaževanja. Vsa se v veliki meri zavedajo okoljskih problemov in redno zagotavljajo obratovalne monitoringe emisij v zrak. Večina parametrov, ki se jih določa v sklopu obratovalnih monitoringov je znotraj predpisanih mejnih vrednosti oz. koncentracij.

Izgorevanje fosilnih goriv v individualnih kuriščih je vir onesnaževanja zraka z žveplovim dioksidom in dimom. Dolgoletne meritve kažejo, da je zrak z $\mathrm{SO}_{2}$ in dimom na območju MOK najbolj onesnažen v hladni polovici leta, v obdobju kurilne sezone. Ustrezna rešitev je uporaba čistejših goriv.

Na območju Mestne občine Koper so z vidika vplivov kakovosti zraka na bivalno okolje, zdravje ljudi, naravo, poškodbe na zgradbah itd. najbolj problematične vrednosti NOx in $\mathrm{O}_{3}$. Zaradi tega in zaradi dostopnih podatkov glede razširjenosti kroničnih obolenj dihal pri otrocih smo v raziskovalni nalogi izpostavili problematiko ozona. Simptomi so bolečine v prsih, kašelj, kihanje, kopičenje krvi v pljučih in nosu, oteženo ali pospešeno dihanje, vneto grlo in draženje v grlu. Ozon pripomore k prezgodnjemu staranju pljuč in k slabitvi srčnega in žilnega sistema. V okolju hudo poškoduje posevke in gozdove, najhuje so prizadeti listi. $\mathrm{S}$ tem je onemogočena fotosinteza, kar povzroča slabšo rast in zmanjša proizvodnjo kisika. Izgube na pridelkih so od 10-20 odstotne. 


\section{HRUP}

Glede na zadnje rezultate meritev (Kvaliteta življenjskega okolja v Koprski občini, 1998), je bilo ugotovljeno, da:

- $\quad$ v II. območje, ki je primarno namenjeno bivanju (nočna mejna raven $45 \mathrm{dBA}$, dnevna 55 dBA) spada celotno območje starega mestnega jedra Kopra ter stanovanjska območja, kot so npr. deli Žusterne, nekatera blokovna naselja, notranji predeli Semedele, ipd. Izjema je razmeroma hrupna neposredna okolica pomembnejših prometnic. Hrup je nekoliko večji tudi v Šalari, kjer je več gospodarskih dejavnosti;

- so bile ob pomembnejših prometnicah ravni hrupa podnevi izmerjene od 65 do $70 \mathrm{dBA}$, ponoči pa od 50 do $60 \mathrm{dBA}$, kar je kar je že na meji kritičnih ravni za III. (nočna mejna raven $50 \mathrm{dBA}$, dnevna $60 \mathrm{dBA}$ ) in II. območje;

- je več stanovanjskih območij z vidika hrupa nadpovprečno ugodnih. Dnevne imisije hrupa spadajo v razred med 45 in $50 \mathrm{dBA}$, nočne pa med 30 in $40 \mathrm{dBA}$. To izpolnjuje zahteve za I. območje (nočna mejna raven 40 dBA, dnevna 50 dBA). Med takšna območja spadajo večji del Žusterne, Markovec, Semedela, Olmo in stanovanjski del Šalare.

Vsak industrijski objekt povzroča določen nivo hrupa, npr. tovarniški kompleks Kemiplasa v Dekanih je od prvih stanovanjskih objektov oddaljen le približno $100 \mathrm{~m}$ in je vsekakor pomemben vir hrupa. Nočna raven hrupa dosega zgornjo dovoljeno mejo, zato so zavezanci v MOK za plačilo takse za obremenjevanje okolja s hrupom in morajo izvajati monitoring vsako tretje leto. Izmerjene podatke posredujejo na MOP. Poleg Kemiplasa je v Dekanih tudi podjetje Lama, ki je prav tako zavezanec za plačilo taks.

Najvplivnejši in najbolj problematičen vir hrupa je promet, saj se je število registriranih motornih vozil v zadnjih letih močno povečalo (Kvaliteta življenjskega okolja v Koprski občini, 1998).

\section{PRST}

Prst v MO Koper je z vidika varstva okolja med najmanj problematičnimi pokrajinskimi elementi. Dejavnosti so razmeščene in zasnovane tako, da prsti pomembneje ne degradirajo. Kaže se izrazita dvojnost med zahodnim (priobalnim) in vzhodnim (zalednim) delom občine. Velika večina dejavnosti je zaradi intenzivne litoralizacije zgoščena v zahodnem delu.

Do degradacije prsti v manjši meri prihaja le lokalno, v ozkem pasu okoli industrijskih obratov, neurejenih, divjih odlagališč odpadkov in ob prometnicah. Ploskovno onesnaževanje predstavlja kmetijstvo, ki pa je intenzivno le na določenih območjih zelenjadarstva, vinogradništva in sadjarstva.

Vse dosedanje meritve onesnaženosti prsti (zelo redke in nesistematične) so pokazale minimalno onesnaženost. Ponekod na območjih intenzivnega sadjarstva, predvsem pa vinogradništva, so bile presežene mejne imisijske vrednosti bakra (fitofarmacevtska sredstva), na nekaterih flišnih območjih pa mejne imisijske vrednosti niklja (matična podlaga).

V določenih delih v porečju Dragonje lapornat fliš, veliki nakloni in padavine v obliki nalivov soustvarjajo ugodne razmere za erozijo prsti, vendar pa se ta v intenzivni obliki vrši le lokalno. Ta problem se uspešno rešuje z urejanjem kulturnih teras. 
Majhne regeneracijske in nevtralizacijske sposobnosti imajo prsti v pokrajinskoekoloških enotah Hribovje Griža - Velika Griža, Zazidsko - Rakitovski rob ter Slavnik. Na območju teh treh pokrajinskoekoloških enot prevladujejo rendzine na apnencu. Na območju pokrajinske enote (PE) Hribovje Griža - Velika Griža se poleg rendzin pojavljajo še karbonatne rjave prsti na eocenskem flišu, na območju Zazidsko - Rakitovski rob najdemo še rjave pokarbonatne prsti na apnencu, na območju PE Slavnik pa najdemo tudi evtričen hipoglej. Ob upoštevanju kmetijske rabe tal v naštetih PE, lahko sklepamo, da kljub majhnim regeneracijskim in nevtralizacijskim sposobnostim prsti na teh območjih niso ogrožene, saj prevladujejo gozdovi in travniki. Poselitev je razpršena, poljedelstvo pa ekstenzivno. Do večjega obremenjevanja prsti prihaja na območju koprskega in ankaranskega zaledja, kjer pa so regeneracijske in nevtralizacijske sposobnosti prsti zmerne do velike. Iz tega sklepamo, da ne prihaja do prekoračitev mejnih vrednosti nevarnih snovi v prsti oziroma so le te prekoračene na manjših površinah (Špes, Cigale, Lampič, Natek, Smrekar 2001).

\section{ODPADKI}

Skupna količina odpadkov narašča, hkrati s tem pa se vzpostavljajo mehanizmi, ki odpadke obvladujejo. Število kontejnerjev na ekoloških otokih (preračunano na prebivalca MO Koper) je večje, kot predpisujejo pravila, deponija Dvori se je v zadnjih letih tehnološko posodobila in zmanjšala vplive na okolje, obratovanje kompostarne pomeni trajno rešitev za velike količine bioloških odpadkov, ki nastajajo bodisi v Luki bodisi na javnih zelenih površinah. Center za ravnanje odpadkov (CERO), ki deluje v okviru Luke Koper, je posredno zmanjšal obremenitve na deponiji Dvori, saj le $20 \%$ odpadkov, ki nastanejo v Luki, konča na deponiji (ostalo se loči in reciklira oziroma sežge v drugih delih Slovenije). V letu 2005 je podjetje Komunala Koper po ekoloških otokih ločeno zbralo več kot 1,4 tone odpadkov, največ od tega je bilo bioloških odpadkov in papirja. Količina stekla se iz leta v leto zmanjšuje, medtem ko se povečuje količina plastične embalaže. Glavni dejavnik pri zmanjšanju količin odpadkov so ljudje sami. Če ne ločujejo odpadkov in v zabojnik za določeno vrsto odpadkov vržejo druge odpadke, je Komunala Koper primorana pomešan material iz celotnega zabojnika odložiti na deponijo v Dvorih, v nasprotnem primeru pa frakcije lahko proda odvzemnim podjetjem in prihrani prostor.

Izzivi, ki ostajajo, so vzpostavitev novega zbirnega centra za Južno primorsko regijo, ki naj bi deloval v MO Koper (ker se na območju Kopra zbere največ odpadkov) in nove regijske deponije odpadkov. Občine Južno primorske regije v skladu s strateškimi državnimi usmeritvami podpirajo regionalni pristop ravnanja z odpadki. V letu 2002 so občine podpisale konzorcialno pogodbo za regijsko ravnanje $\mathrm{z}$ odpadki in tako ustanovile Konzorcij GOJUP. Država je Konzorciju omogočila koriščenje okoljskih dajatev za regijske investicije in lokalno urejenje zbirnih centrov in obstoječih odlagališč. Po spremenjenih razmerah na področju ravnanja z odpadki (leta 2008 se bodo zaprla vsa odlagališča na razpoklinskem kraškem terenu) in mnenju ljudi o primernosti obremenitve sežanske občine se je Konzorcij odločil, da bodo za vse občine skupaj zgradili dva regionalna centra za ravnanje z odpadki, ki bosta imela vsak drugačni funkciji:

- regijski CERO Koper, v katerem bo potekala obdelava ločeno zbranih frakcij. Vsebuje: 
sortirnico, kompostarno, demontažo kosovnih odpadkov in bele tehnike, zbirni center in pretovorno postajo;

- regijski CERO, kjer bo potekala mehanska biološka obdelava preostanka odpadkov in njihovo odlaganje na površini s $500.000 \mathrm{~m}^{3}$ volumna.

$\mathrm{V}$ okviru drugega regijskega centra je zaključena študija »Izbor in ocena primernosti potencialnih lokacij za regijsko odlagališče komunalnih odpadkov«, ki jo je izdelal Geološki zavod Slovenije. Študija je iskala najprimernejša območja znotraj osmih občin za umestitev drugega regijskega centra. Lokacij je 16, občine pa jih morajo oceniti z vidika družbene sprejemljivosti in izbrati najprimernejšo.

Grafikon 1: Ločeno zbrane frakcije v letu 2005

Graph 1: Separatly collected fractions in 2005

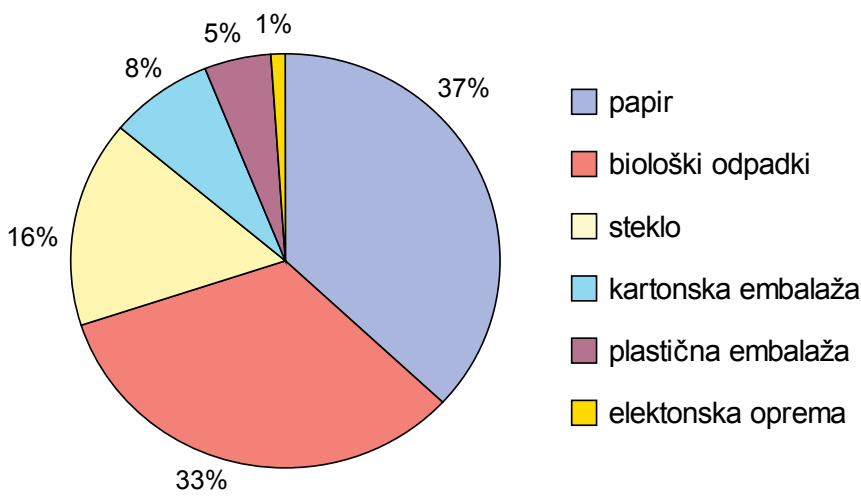

Vir: Medmrě̌je 2: Komunala Koper, 2006.

\section{ZAVAROVANA OBMOČJA}

Zakon o ohranjanju narave iz leta 1999, ki je bil že večkrat dopolnjen. Z omenjenim zakonom so opredeljena zavarovana območja na dveh nivojih. V skupino širših zavarovanih območij sodijo narodni park, regijski parki in krajinski parki, v skupino ožjih zavarovanih območij pa strogi naravni rezervati, naravni rezervati in naravni spomeniki.

Na območju Mestne občine Koper je samo en naravni rezervat - Škocjanski zatok ter en naravni spomenik - Debeli rtič, predvidena pa je ustanovitev krajinskega parka Dragonja, katerega večji del bi se razprostiral na ozemlju Mestne občine Koper. Ob vzhodnem robu občine pa naj bi nastal Kraški regijski park, ki bi svoj osrednji del imel izven občine.

Poleg širših in ožjih zavarovanih območij pa Zakon o ohranjanju narave opredeljuje posebna varstvena območja, ki predstavljajo ekološko pomembna območja za ohranitev ali doseganje ugodnega stanja vrst, njihovih habitatov in habitatnih tipov, ki so poznana pod imenom Natura 2000. Direktiva o habitatih določa na območju občine sedem območij (Škocjanski zatok, Debeli rtič - klif, Slovenska Istra - območje reke Dragonje, Kras, Ankaran - Sv. Nikolaj, Pregara - travišča, Žusterna - rastišče pozejdonke), direktiva o pticah pa 
dve območji (Škocjanski zatok, Kras - tudi izven meja občine).

Karta 2: Zavarovana območja v MO Koper

Map 2: Terrestrial and marine protected areas in the Municipality of Koper

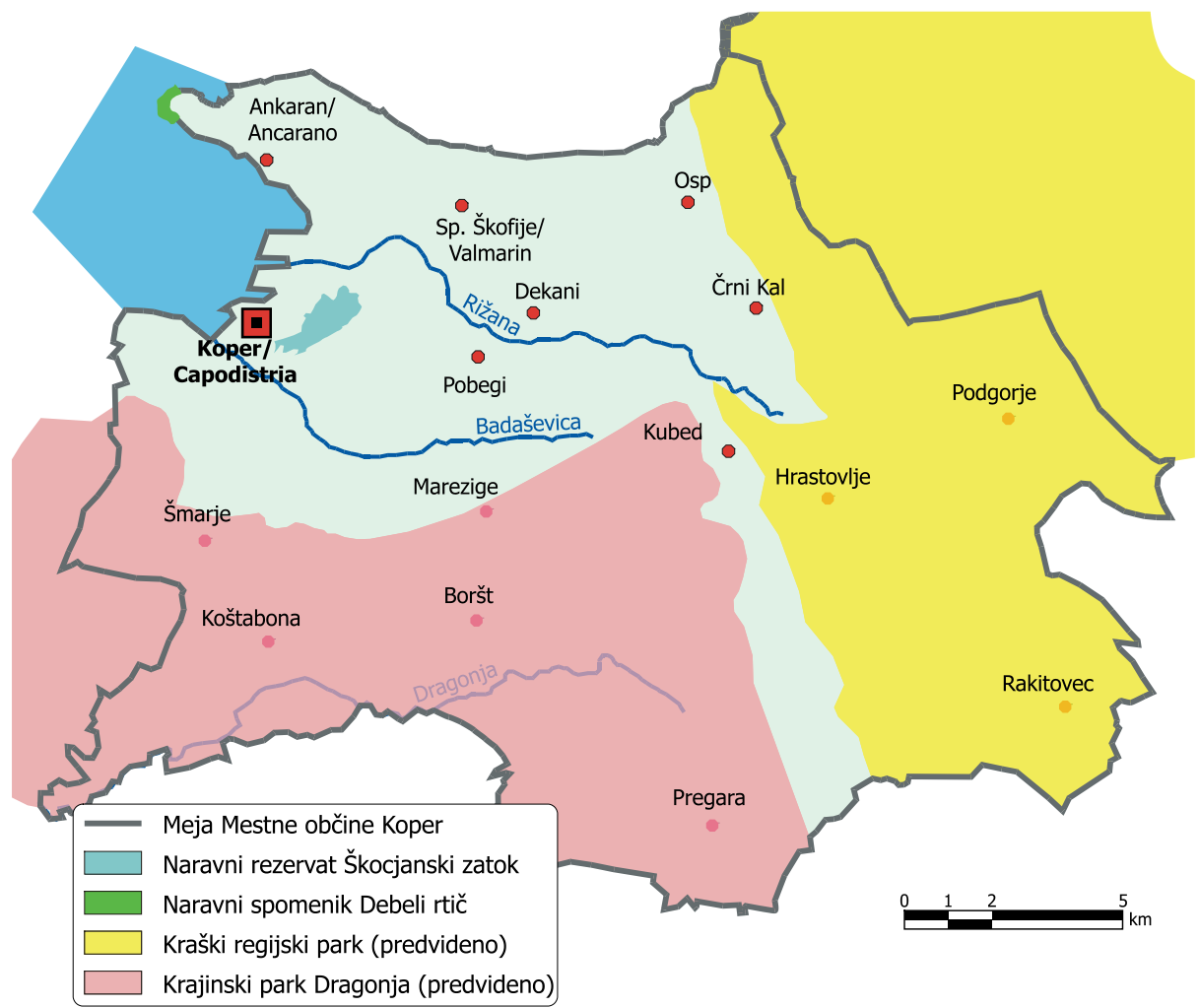

Avtor: Novak, 2006.

\section{SKLEP}

Mesto Koper je regionalno središče, ki se je začelo hitro razvijati po letu 1954, ko je postalo del ozemlja nekdanje države Jugoslavije in je Luka Koper začela pridobivati na svojem pomenu. Hiter razvoj industrije in prometa je pritegnil priseljence iz ostalih delov države, zato se je število prebivalcev naglo povečevalo. Po osamosvojitvi Slovenije pa Koper postane najpomembnejše prometno izhodišče Slovenije, saj ima edino slovensko pristanišče. Hiter razvoj je s seboj prinesel tudi negativne posledice in okoljske probleme. Zgoščeni prometni tokovi, katerim je izpostavljeno območje MO Koper, poleg pozitivnih učinkov, ki so predvsem ekonomske narave, predstavljajo tudi povečan pritisk na okolje. Velik pritisk na okolje, predvsem na vodne vire, povzročata še gosta poselitev v ozkem obalnem pasu in intenzivno 
kmetovanje v njegovem zaledju. Dodaten okoljski pritisk pa povzroča še sezonski turizem, zaradi katerega se še povečajo prometni tokovi in število prebivalcev. Na proučevanem območju se nahajajo tudi zavarovana območja narave, kjer so zaradi različnih varstvenih režimov pritiski gospodarskih dejavnosti manjši, zato ta območja izkazujejo večjo kvaliteto okolja.

Stanje okolja v MO Koper v primerjavi z drugimi območji v Sloveniji ni kritično. Onesnaženju je najbolj izpostavljen priobalni del občine zaradi procesa litoralizacije, še posebej obremenjujoči so poletni meseci. Najmanj problematična sestavina okolja je prst, saj se največji onesnaževalci nahajajo na manj kvalitetnih prsteh. MO Koper lahko s svojo politiko delovanja še veliko vpliva na zmanjšanje onesnaženosti vseh predstavljenih pokrajinotvornih sestavin.

\section{Viri in literatura}

Kataster onesnaževalcev v Mestni občini Koper, končno poročilo. Domžale.

Kvaliteta življenjskega okolja v koprski občini. 1998. Inštitut za geografijo, Ljubljana.

Lavrič, S., Novak, M. et al. 2006. Poročilo o stanju okolja v Mestni občini Koper. Raziskovalna naloga, Oddelek za geografijo, Filozofska fakulteta. Ljubljana.

Plut, D. 2004. Geografske metode proučevanja degradacije okolja. Oddelek za geografijo, Filozofska fakulteta, Ljubljana.

Poklar, A. 2006. Hrup v Mestni občini Koper. Osebni vir.

Proučevanje vpliva okolja na pojav določenih bolezni in povečano stopnjo umrljivosti prebivalcev na območju dela Mestne občine Koper, 2003. Zavod za zdravstveno varstvo Celje.

Rejec Brancelj, I. 1993. Agrarnogeografska problematika Koprskega primorja z vidika varstva okolja. Magistrsko delo, Oddelek za geografijo, Filozofska fakulteta. Ljubljana

Špes, M., Cigale, D., Lampič, B., Natek, K., Smrekar, A. 2001. Ranljivost okolja na območju Mestne občine Koper. Inštitut za geografijo. Ljubljana.

Das DPSIR - Modell professioneller Umwelttätigkeiten. Medmrežje: http://www.mieg.ethz. ch/about/DPSIR (citirano: april 2006).

Medmrežje 1: Javno podjetje vodovod - kanalizacija Ljubljana. URL: http://www.jh-lj.si/upload/doc/284_Cenik__pitna_voda.pdf (citirano: maj 2006).

Medmrežje 2: Komunala Koper, 2006. URL: http://www.komunalakoper.si/index.php?page $=$ static\&id=60\&item $=5 \&$ grp=kanalizacijski_sistem\&sklop $=0$ (citirano: april 2006).

Medmrežje 3: Mestna občina Koper. URL: http://www.koper.si/dokument.aspx?id=3901 (citirano: april 2006).

Medmrežje 4: Rižanski vodovod Koper, 2006. URL: http://www.rvk-jp.si/ (citirano: april 2006).

Monitoring kakovosti morja, brakičnih voda in voda za življenje in rast morskih školjk in morskih polžev v letu 2005. Medmrežje: http://www.arso.gov.si/podro cja/vode/ poro cila_in_publikacije/povrsinske_letna.html (citirano: april 2006).

Povzetek poročila o stanju okolja v MOK. 2003. Medmrežje: http://www.koper.si/dokument. aspx?id=5775 (citirano: april 2006). 


\title{
REPORT ON THE STATE OF THE ENVIRONMENT IN THE MUNICIPALITY OF KOPER
}

\begin{abstract}
Summary
The city of Koper is a regional centre that began its fast development after 1954 when it became a part of, now former, Yugoslavia and when the Port of Koper started to gain influence. Swift industrial and transportational development attracked immigrants from all over the country which caused immense population growth. After Slovenia achieved independence the city of Koper became the most imortant traffic starting-point for the new-founded country because it is the only Slovenian port. Intensive economical growth brought negative consequences and ecological problems. Transport flows that are concentrated in the Municipality of Koper not only bring positive effects of economical nature, but also an increase of pressures on the environment. Those pressures, mainly on the water sources, are amplified by dense population in the narrow coast-line and intensive farming in the hinterland. An additional pressure is brought by seasonal turism that increases the effects of traffic and population related pollution. There are also terrestrial and marine protected areas in the researched area that are under different protection regimes which in turn lessen the pressures from economic activity, hence better environment quality in such areas.

In comparison with the rest of Slovenia the state of the environment in the Municipality of Koper is not critical. Due to the proces of litoralisation the most subjected area to pollution is the narrow coast-line, especially in the summer months. The least problematic environmental component is soil on account of all the major polluters being situated on less favourable soils. The Municipality of Koper has serious potential to diminish pollution of all the environmental components with its general policy.
\end{abstract}

